Research Article

\title{
Assessment of median lethal dose and anti-mutagenic effects of Glycyrrhiza glabra root extract against chemically induced micronucleus formation in Swiss albino mice
}

\author{
Varsha Sharma $^{1 *}$, R. C. Agrawal ${ }^{1}$, Vinoy K. Shrivastava ${ }^{2}$
}

\author{
${ }^{1}$ Department of Research, \\ Priyamvada Birla Cancer \\ Research Institute, M. P. Birla \\ Hospital, Satna - 485 005, \\ Madhya Pradesh, India, \\ ${ }^{2}$ Department of Bioscience, \\ Barkatullah University, \\ Bhopal, Madhya Pradesh, \\ India
}

Received: 09 January 2014 Accepted: 02 February 2014

\author{
*Correspondence to: \\ Varsha Sharma, \\ Email: varshas81@gmail.com \\ (C) 2014 Sharma V et al. This \\ is an open-access article \\ distributed under the terms \\ of the Creative Commons \\ Attribution Non-Commercial \\ License, which permits \\ unrestricted non-commercial \\ use, distribution, and \\ reproduction in any medium, \\ provided the original work is \\ properly cited.
}

\begin{abstract}
Background: To assess the median lethal dose and evaluate the anti-chemotherapeutic effects of hydro-methanolic root extract of Glycyrrhiza glabra on the cyclophosphamide (CP) induced mutagenicity in bone marrow cells of Swiss albino mice.

Methods: For the assessments of $\mathrm{LD}_{50}$, hydro-methanolic root extract of Glycyrrhiza glabra were intra-peritoneally administered at doses of 200, 400, 600, 800, 1000, and $1200 \mathrm{mg} / \mathrm{kg}$ body weight. For the mutagenicity study, bone marrow micronucleus test was used and the single i.p. of Glycyrrhiza glabra extract given at the dose of 300,450 , and $600 \mathrm{mg} / \mathrm{kg}$ body weight, $24 \mathrm{hrs}$ prior the administration of CP (at the dose of $50 \mathrm{mg} / \mathrm{kg}$ body weight).

Results: The present investigations revealed that, the median lethal dose/ $\mathrm{LD}_{50}$ was observed at the dose of $833.3 \mathrm{mg} / \mathrm{kg}$ body weight. The results suggest that, the doses of 450 and $600 \mathrm{mg} / \mathrm{kg}$ body weight expressed significant preventive potential against $\mathrm{CP}$ induced Micronucleus formation in student ' $\mathrm{t}$ ' test at dose dependent manner in the bone marrow cells of Swiss albino mice. Glycyrrhiza glabra root extract alone has not induced micronucleus formation.

Conclusion: Based on this study, it may be concluded that Glycyrrhiza glabra root extract possess anti-mutagenic behavior and this hydro-methanolic crude extract may be safe as per the $\mathrm{LD}_{50}$ was observed.
\end{abstract}

Keywords: Bone marrow, Cyclophosphamide, Glycyrrhiza glabra, Micronucleus assay, Mutagenicity, Toxicity

\section{INTRODUCTION}

Plants have been used for medicinal purposes since before recorded history. Since the origin of human's life, plants continue to play a curative and therapeutic role in preserving human health against disease. An $\mathrm{LD}_{50}$ is a standard measurement of acute toxicity that is stated in milligrams $(\mathrm{mg})$ of extract material per kilogram $(\mathrm{kg})$ of body weight. A process by which the genetic information of an organism is changed in a stable manner, resulting in a mutation is known as mutagenesis or mutagenicity. A micronucleus is the erratic (third) nucleus that is formed during the anaphase of mitosis or meiosis and also referred to Howell-Jolly bodies. Micronuclei are characterized as newly divided daughter cell, which can contain a whole chromosome or part of a chromatid in the cells. This includes damage caused by radiation, harmful chemicals, and random mutations that occur throughout the genome.

Glycyrrhiza glabra (G. glabra L.; Family: Fabaceae) is a traditional medicinal herb, which grows in various parts of the world. This herb is known as 'mulaithi' in northern India and roots are called as Licorice commonly. The yellow color of licorice is due to the flavonoid content of the plant, which includes liquiritin, isoliquiritin (a chalcone) , and other compounds. ${ }^{1}$ The roots and rhizomes of Glycyrrhiza glabra have been widely used in medicines for its unique and diverse pharmacological properties viz., antiviral, anticancer, anti-ulcer, anti-diabetic, antiinflammatory, immunostimulant, anti-allergenic, etc. ${ }^{2,3}$ In addition, the roots are also used as a flavoring and sweetening agents with tobacco chewing, chewing gums, 
candies, toothpaste, and beverages. ${ }^{4}$ Phytochemical investigations have demonstrated that the major bioactive components of Glycyrrhiza glabra roots are flavonoids and pentacyclic triterpene saponin, Alkaloids, Glycosides, etc. The hydromethanolic root extract possess anti-bacterial and antioxidant potential because the presence of these secondary metabolites or phytoconstituents. ${ }^{5}$ Liquorice is effective in the reducing of pain and inflammation of stomatitis mouth ulcers by the reduction in ulcer size and speed healing. ${ }^{6}$

\section{METHODS}

\section{Plant collection and identification}

The root of Glycyrrhiza glabra were procured from Bhopal (Madhya Pradesh), India and authenticated by Botanist, Dr. Zia Ul Hasan (Voucher Specimen No: 441/BOT/Safia/13) Prof. \& Head, Dept. of Botany, Safia Science College, Bhopal, Madhya Pradesh (India).

\section{Chemicals}

Cyclophosphamide (CP) was purchased from Sigma chemical Co., U.S.A. HBSS, albumin, EDTA, saline, methanol, May-Grunwald, Giemsa, and other chemicals were reagents grade.

\section{Preparation of Glycyrrhiza glabra root extract}

The collected root were dried in the shade and grinded with mechanical grinder. About $30 \mathrm{~g}$ powder was filled in a separating funnel with $50 \%$ methanol for $48 \mathrm{hrs}$. The collected residues kept at $55-60^{\circ} \mathrm{C}$ in boiling water bath to concentrate it and finally transfer into the hot air oven to dry it. About $5.8 \mathrm{~g}$ powder of crude extract was obtained (yield $=19 \%)$ and used for the further studies.

\section{Experimental animals}

Random bred of male Swiss albino mice (7-8 weeks old), weighing $23 \pm 2 \mathrm{~g}$ body weight obtained from the animal colony of our Research Center were used for the experiments. Experimental animals were handled according to the Institutional Legislation, regulated by the Committee for the purpose of Control and Supervision of Experiments on Animals, Ministry of Social Justice and Empowerment, Government of India. These animals were housed in polypropylene cages in the animal house at temperatures of $22 \pm 1.5^{\circ} \mathrm{C}$ and $12 \mathrm{hrs}$ light and dark cycle. The animals were provided with standard pallet diet (from Golden feed Ltd., New Delhi, India) and water ad libitum.

\section{Experimental design}

Acute toxicity study (median lethal dose $/ L D_{50}$ )

Acute intra-peritoneal toxicity test was performed as per OECD-423 guidelines. All the animals were randomly distributed into one control and six experimental groups, containing six animals per group. All groups were intraperitoneally administered 200, 400, 600, 800, 1000 and $1200 \mathrm{mg} / \mathrm{kg}$ body weight hydro-methanolic extract of Glycyrrhiza glabra and the control group received vehicle alone (double distilled water [DDW]) by oral route using intragastric syringe following the method of Lorke. ${ }^{7}$ The animals were observed continuously for first $72 \mathrm{hrs}, 7$ days and after those 14 days for any signs of behavioral changes, toxicity, mortality, and body weight.

The median lethal dose $\left(\mathrm{LD}_{50}\right)$ calculated as, the dose at which 50\% mortality was observed during 2 weeks. The animals were observed and the studies were terminated after 2 weeks. The $\mathrm{LD}_{50}$ value was calculated with "Arithmetic method of Karber." ${ }^{9,9}$

The sum of the product was divided by the number of animals in a group and the resulting quotient was subtracted from the least lethal dose in order to obtain $\mathrm{LD}_{50}$ value.

$\mathrm{LD}_{50}=$ the apparent least dose lethal to all in a group $-(a . b) / N$

Where $N=$ number of animals in each group.

$a=$ dose difference.

$b=$ mean mortality.

Anti-mutagenic activity (micronucleus assay)

Micronucleus assay test was performed as per the method reported by $\mathrm{Schmid}^{10}$ and modified by Aron et al. ${ }^{11}$ and standardized by Agrawal et al., 1998. ${ }^{12}$ The animals were randomly divided into six groups and each group having four mice. The required dose was dissolved in an appropriate solvent (DDW) and administered intraperitoneally before 24 hrs of CP treatment. Positive control group was received only $\mathrm{CP}$ injection. The animals were sacrificed after $24 \mathrm{hrs}$ of CP administration and slides of Bone marrow were prepared. After staining with May-Grunewald and Giemsa, total of 1000 cells were scored at magnification of $\times 1000(100 \times 10)$ for each group.

\section{Experimental groups}

Group I (vehicle alone): Double distilled water (DDW).

Group II (positive control): Single i.p. of CP $(50 \mathrm{mg} / \mathrm{kg}$ body weight) administered. 
Group III (Glycyrrhiza glabra extract alone): Single i.p. of $300 \mathrm{mg} / \mathrm{kg}$ body weight of Glycyrrhiza glabra hydromethanolic root extract.

Group IV (Glycyrrhiza glabra extract $+\mathrm{CP}): 300 \mathrm{mg} / \mathrm{kg}$ body weight of Glycyrrhiza glabra hydromethanolic root extract before $24 \mathrm{hrs}$ of CP $50 \mathrm{mg} / \mathrm{kg}$ body weight.

Group V (Glycyrrhiza glabra extract + CP): $450 \mathrm{mg} / \mathrm{kg}$ body weight of Glycyrrhiza glabra hydromethanolic root extract before $24 \mathrm{hrs}$ of CP $50 \mathrm{mg} / \mathrm{kg}$ body weight.

Group VI (Glycyrrhiza glabra extract + CP): $600 \mathrm{mg} / \mathrm{kg}$ body weight of Glycyrrhiza glabra hydromethanolic root extract before $24 \mathrm{hrs}$ of CP $50 \mathrm{mg} / \mathrm{kg}$ body weight.

\section{Statistical analysis}

The experimental results were expressed as mean \pm standard error mean. Data were assessed followed by student ' $t$ ' test. $\mathrm{p}<0.05$ was considered as statistically significant.

\section{RESULTS}

\section{Toxicological study}

The results of the toxicity study revealed that different groups treated with hydromethanolic Glycyrrhiza glabra root extract showed no specific signs and mortality was compared to the control group i.e. Vehicle alone (DDW). The all mice moved well and fed normally and no significant change was found on the body weight of mice up to the dose of $600 \mathrm{mg} / \mathrm{kg}$ body wt when compared with the untreated control group.
The behavior of mice has changed at the dose of $800 \mathrm{mg} / \mathrm{kg}$ body wt and loss of body weight of mice was observed. Some mice showed signs and symptoms such as; general weakness, loss of appetite, restlessness, and sleepy behavior after the increasing of dose as dose depending manner. All mice were died at the dose of $1200 \mathrm{mg} / \mathrm{kg}$ body weight. As per the calculation by "Arithmetic method of Karber," the $\mathrm{LD}_{50}$ was observed at the dose of $833.3 \mathrm{mg} / \mathrm{kg}$ body weight. Results are summarized in Table $1 \mathrm{a} \& 1 \mathrm{~b}$.

\section{Anti-mutagenic activity}

The results revealed that, when the $\mathrm{CP}$ given at a single dose i.e. $50 \mathrm{mg} / \mathrm{kg}$ body weight cause a high incidence of micronucleus formation in bone marrow cells of Swiss albino mice (positive control group i.e. Group I) and caused bone marrow toxicity as evidenced by a decrease in the polychromatic erythrocyte/normochromatic erythrocyte ratio. The frequency of micronucleated polychromatic erythrocyte (MNPCEs) was $4.33 \pm 0.61$ for the CP $(50 \mathrm{mg} / \mathrm{kg}$ body weight) treated group which was significantly higher in student ' $t$ ' test at $\mathrm{p}<0.05$. The frequency of MNPCEs in the Group III, i.e. Glycyrrhiza glabra extract alone, at the concentration of $300 \mathrm{mg} / \mathrm{kg}$ body weight was found $0.34 \pm 0.21$, when compared with the untreated control group, it was revealed that the extract was not genotoxic to the bone marrow cells of mice. The mice which received single application of Glycyrrhiza glabra root extract at doses of $300,450,600 \mathrm{mg} / \mathrm{kg}$ body weight $24 \mathrm{hrs}$ before the single administration of $\mathrm{CP}$ at the dose of $50 \mathrm{mg} / \mathrm{kg}$ body weight exhibited significant reduction in the micronucleus formation when compared to the positive control group. Group V (Glycyrrhiza glabra $450 \mathrm{mg} / \mathrm{kg}+$ CP $50 \mathrm{mg} / \mathrm{kg}$ body weight) \& Group VI (Glycyrrhiza glabra 600mg/kg + CP 50mg/kg

Table 1a: The effect of Glycyrrhiza glabra hydromethanolic root extract on mortality and body weight of Swiss albino mice over a period of 2 weeks.

\begin{tabular}{|c|c|c|c|c|c|c|c|}
\hline \multirow{2}{*}{\multicolumn{2}{|c|}{$\begin{array}{l}\text { Sr. No. of } \\
\text { No. mice }\end{array}$}} & \multirow[t]{2}{*}{$\begin{array}{l}\text { Treatment doses } \\
\text { (mg/kg body weight) }\end{array}$} & \multirow[t]{2}{*}{$\begin{array}{l}\text { Rout of } \\
\text { administration }\end{array}$} & \multirow{2}{*}{$\begin{array}{l}\text { Percentage } \\
\text { of mice } \\
\text { died }(\%)\end{array}$} & \multicolumn{3}{|c|}{$\begin{array}{l}\text { Observation of body weight in days } \\
\text { mean } \pm \text { SEM }\end{array}$} \\
\hline & & & & & 0 day & 7 days & 14 days \\
\hline 1. & 06 & $\begin{array}{l}\text { Vehicle alone/positive } \\
\text { control (DDW) }\end{array}$ & $\mathrm{PO}$ & - & $27.20 \pm 0.20$ & $27.90 \pm 0.20$ & $28.50 \pm 1.20$ \\
\hline 2. & 06 & $\begin{array}{l}\text { Glycyrrhiza glabra root extract } \\
\text { ( } 200 \mathrm{mg} / \mathrm{kg} \text { body weight) }\end{array}$ & IP & - & $22.20 \pm 0.34$ & $23.50 \pm 0.50$ & $24.50 \pm 0.22$ \\
\hline 3. & 06 & $\begin{array}{l}\text { Glycyrrhiza glabra root extract } \\
\text { (400 mg/kg body weight) }\end{array}$ & IP & - & $24.33 \pm 0.42$ & $25.20 \pm 0.32$ & $26.30 \pm 0.80$ \\
\hline 4. & 06 & $\begin{array}{l}\text { Glycyrrhiza glabra root extract } \\
\text { ( } 600 \mathrm{mg} / \mathrm{kg} \text { body weight) }\end{array}$ & IP & - & $24.70 \pm 0.21$ & $25.60 \pm 0.68$ & $26.8 \pm 1.2$ \\
\hline 5. & 06 & $\begin{array}{l}\text { Glycyrrhiza glabra root extract } \\
\text { ( } 800 \mathrm{mg} / \mathrm{kg} \text { body weight) }\end{array}$ & IP & 50 & $27.18 \pm 0.34$ & $20.74 \pm 1.2$ & $17.4 \pm 0.3$ \\
\hline 6. & 06 & $\begin{array}{l}\text { Glycyrrhiza glabra root extract } \\
\text { (1000 mg/kg body weight) }\end{array}$ & IP & 83.33 & $29.50 \pm 0.45$ & 25.34 & 24.86 \\
\hline 7. & 06 & $\begin{array}{l}\text { Glycyrrhiza glabra root extract } \\
\text { (1200 mg/kg body weight) }\end{array}$ & IP & 100 & $29.15 \pm 1.22$ & Death & Death \\
\hline
\end{tabular}

Data (body weight) presented as the mean and standard error mean among mice (n=6). IP: Intra-peritoneal, PO: Per os (oral) 
body weight) expressed significant in the student ' $t$ ' test at $\mathrm{p}<0.05$. The results suggest that, the percentage of protection in the frequency of $\mathrm{CP}$-induced $\mathrm{MN}$ formation was significantly increased in a dose dependent manner. Therefore, it appears that Glycyrrhiza glabra extract showed anti-mutagenic potential. Results are summarized in Table 2. Figure 1 showing MNPCE and graphical representation of anti-mutagenic effects in Figure 2, Figure 3, Figure 4.

\section{DISCUSSION}

Acute toxicity test gives clues on the range of doses that could be toxic to the animal; it could also be used to estimate the therapeutic index $\left(\mathrm{LD}_{50} / \mathrm{ED}_{50}\right)$ of drugs and xenobiotics. ${ }^{13}$ The supplementation of Glycyrrhiza glabra extract elevated blood pressure. This is thought to be due to the effect of extract on the rennin-angiotensinaldosterone system. Phytochemicals are thought to have positive or negative effects on animals. In addition to hypertension, extract showed hypokalemia (potassium loss) and sodium retention, resulting in edema. ${ }^{14}$ Tannins and Flavonoids are thought to have both pro-oxidant and antioxidant effects on the body. While the antioxidant protects the tissues and organs, the pro-oxidant damages the tissues and organs. The weight changes of the animals during the period of observation which was more visible

Table 1b: Arithmetic calculation of $\mathrm{LD}_{50}$ by Karber method.

\begin{tabular}{|c|c|c|c|c|c|c|}
\hline $\begin{array}{l}\text { Sr. } \\
\text { No. }\end{array}$ & $\begin{array}{l}\text { No. of mice } \\
\text { in groups }\end{array}$ & $\begin{array}{l}\text { Treatment doses } \\
\text { (mg/kg body weight) }\end{array}$ & $\begin{array}{l}\text { Dose } \\
\text { difference }\end{array}$ & $\begin{array}{l}\text { No. of } \\
\text { death }\end{array}$ & $\begin{array}{l}\text { Mean } \\
\text { death }\end{array}$ & $\begin{array}{l}\text { Dose difference } \\
\mathrm{X} \text { mean death }\end{array}$ \\
\hline \multirow[t]{2}{*}{1.} & 06 & $\begin{array}{l}\text { Glycyrrhiza glabra root extract } \\
\text { ( } 200 \mathrm{mg} / \mathrm{kg} \text { body weight) }\end{array}$ & & - & & \\
\hline & & & 200 & & - & - \\
\hline \multirow[t]{2}{*}{2.} & 06 & $\begin{array}{l}\text { Glycyrrhiza glabra root extract } \\
\text { ( } 400 \mathrm{mg} / \mathrm{kg} \text { body weight) }\end{array}$ & & - & & \\
\hline & & & 200 & & - & - \\
\hline \multirow[t]{2}{*}{3.} & 06 & $\begin{array}{l}\text { Glycyrrhiza glabra root extract } \\
(600 \mathrm{mg} / \mathrm{kg} \text { body weight) }\end{array}$ & & - & & \\
\hline & & & 200 & & 1.5 & 300 \\
\hline \multirow[t]{2}{*}{4.} & 06 & $\begin{array}{l}\text { Glycyrrhiza glabra root extract } \\
\text { ( } 800 \mathrm{mg} / \mathrm{kg} \text { body weight) }\end{array}$ & & 3 & & \\
\hline & & & 200 & & 4 & 800 \\
\hline \multirow[t]{2}{*}{5.} & 06 & $\begin{array}{l}\text { Glycyrrhiza glabra root extract } \\
\text { (1000 mg/kg body weight) }\end{array}$ & & 5 & & \\
\hline & & & 200 & & 5.5 & 1100 \\
\hline 6. & 06 & $\begin{array}{l}\text { Glycyrrhiza glabra root extract } \\
\text { (1200 mg/kg body weight) }\end{array}$ & & 6 & & \\
\hline
\end{tabular}

$\mathrm{LD}_{50}:$ Lowest dose that killed $100 \%-\Sigma$ dose difference $\times$ mean death $/ \mathrm{N}, \mathrm{LD}_{50}: 833.3 \mathrm{mg} / \mathrm{kg}$ body weight

Table 2: The effects of Glycyrrhiza glabra hydro-methanolic root extract against micronucleus formation by cyclophosphamide in bone marrow cells of Swiss albino mice.

\begin{tabular}{|c|c|c|c|c|c|}
\hline $\begin{array}{l}\text { Sr. } \\
\text { No. }\end{array}$ & Groups & Treatment doses (mg/kg body weight) & MNPCE \pm SEM & $\begin{array}{l}\mathrm{PCE} / \mathrm{NCE} \\
\text { ratio } \pm \mathrm{SEM}\end{array}$ & $\begin{array}{l}\text { Protection } \\
(\%)\end{array}$ \\
\hline 1. & $\mathrm{I}(\mathrm{n}=4)$ & $\begin{array}{l}\text { Cyclophosphamide alone } \\
\text { ( } 50 \mathrm{mg} / \mathrm{kg} \text { body weight) }\end{array}$ & $4.33 \pm 0.61$ & $1.13 \pm 0.18$ & - \\
\hline 2. & II $(n=4)$ & $\begin{array}{l}\text { Glycyrrhiza glabra }(300 \mathrm{mg} / \mathrm{kg} \text { body weight })+ \\
\text { CP }(50 \mathrm{mg} / \mathrm{kg} \text { body weight })\end{array}$ & $2.34 \pm 0.49$ & $0.99 \pm 0.02$ & 45.95 \\
\hline 3. & III $(n=4)$ & $\begin{array}{l}\text { Glycyrrhiza glabra ( } 450 \mathrm{mg} / \mathrm{kg} \text { body weight })+ \\
\text { CP ( } 50 \mathrm{mg} / \mathrm{kg} \text { body weight })\end{array}$ & $1.5 \pm 0.93 *$ & $1.06 \pm 0.05$ & 65.35 \\
\hline 4. & $\mathrm{IV}(\mathrm{n}=4)$ & $\begin{array}{l}\text { Glycyrrhiza glabra }(600 \mathrm{mg} / \mathrm{kg} \text { body weight })+ \\
\text { CP }(50 \mathrm{mg} / \mathrm{kg} \text { body weight })\end{array}$ & $0.67 \pm 0.34^{*}$ & $1.02 \pm 0.03$ & 84.52 \\
\hline 5. & $V(n=4)$ & $\begin{array}{l}\text { Glycyrrhiza glabra alone } \\
\text { ( } 300 \mathrm{mg} / \mathrm{kg} \text { body weight) }\end{array}$ & $0.34 \pm 0.21$ & $1.02 \pm 0.02$ & - \\
\hline 6. & $\mathrm{VI}(\mathrm{n}=4)$ & Vehicle alone (DDW) & $0.12 \pm 0.08$ & $0.43 \pm 0.08$ & - \\
\hline
\end{tabular}

*Statistical significance as compared to cyclophosphamide at $\mathrm{P}<0.05$ followed in student ' $\mathrm{t}$ ' test. PCE: Polychromatic erythrocyte, NCE:

Normochromatic erythrocyte, MNPCE: Micronucleated polychromatic erythrocyte, SEM: Standard error mean 


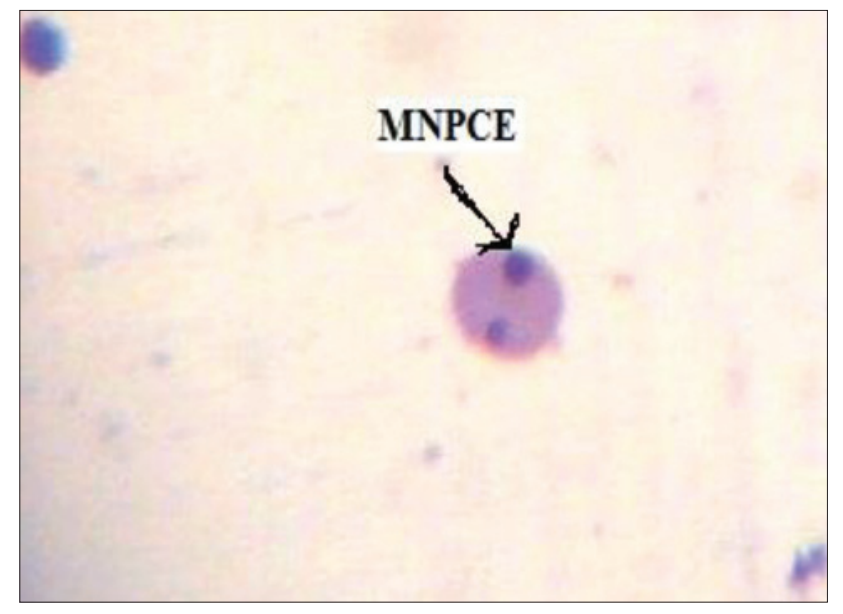

Figure 1: Micronuleated polychromatic erythrocyte.

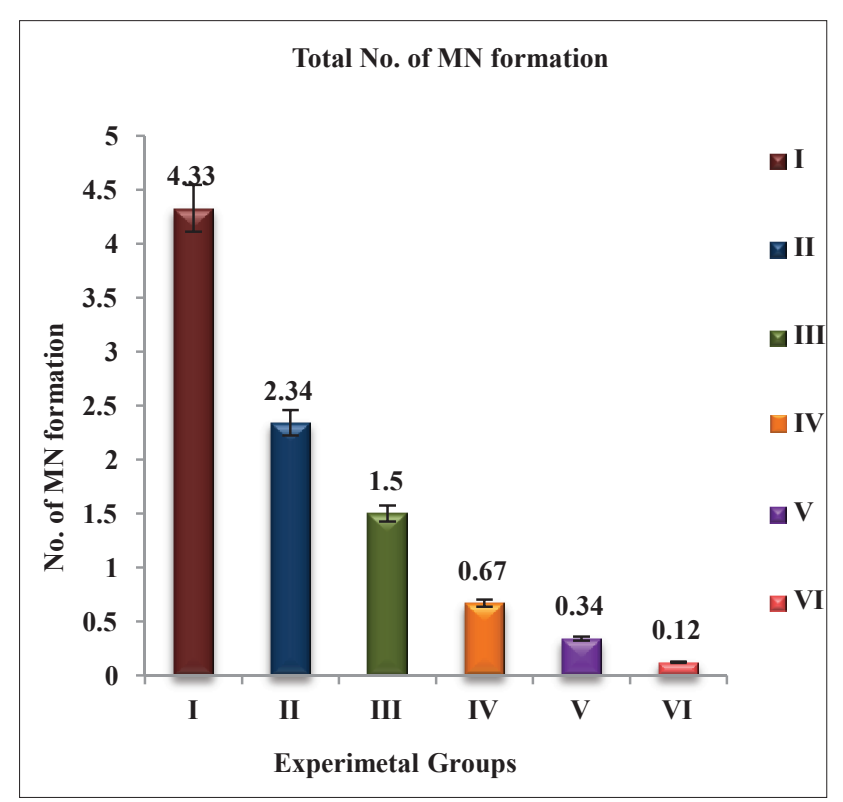

Figure 2: Effect of G. glabra root extract on MN formation.

at higher doses, suggest the presence of tannins which are thought to interfere with the absorption of nutrients making them unavailable and thereby reducing feed intake. ${ }^{15}$

Traditionally, the plant has been recommended as a prophylaxis for gastric and duodenal ulcers and dyspepsia as an anti-inflammatory agent during allergenic reactions. ${ }^{16}$ The aqueous extract, or Glycyrrhiza glabra inhibits in vivo and in vitro proliferation of Ehrlich ascites tumor cells and inhibits angiogenesis in in vivo assay, peritoneal and chorioallantoic membrane assay. ${ }^{17}$

$\mathrm{CP}$ is belongs a class of drugs known as alkylating agent, which have been used to treat some kind of cancer. After studying the mode of action of $\mathrm{CP}$, it demonstrated that, this induces inhibition of deoxyribonucleic acid (DNA) replication and leading cell death. CP exerts its cytotoxic

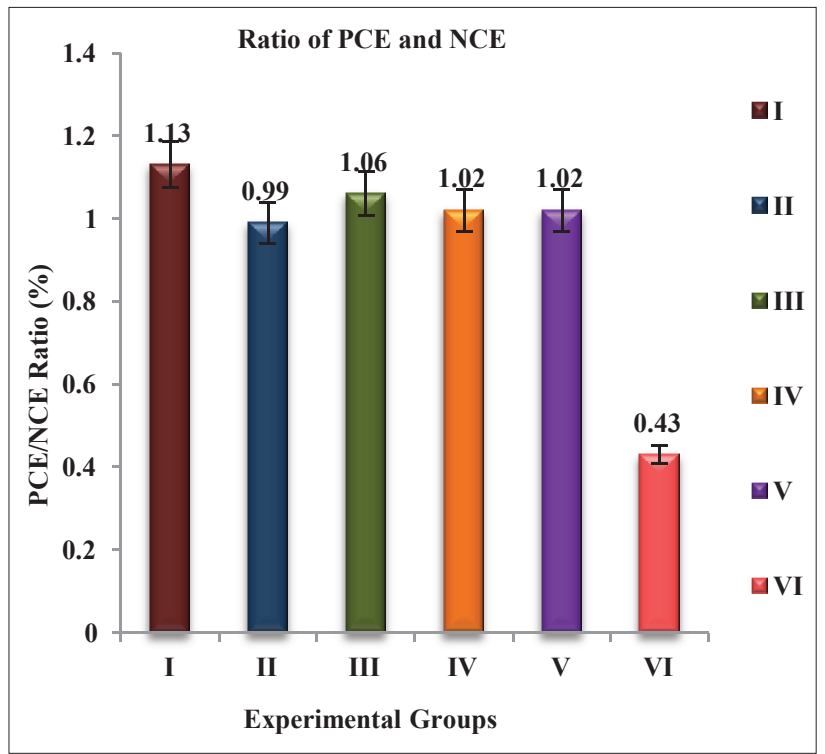

Figure 3: Effect of G. glabra root extract on PCE/NCE Ratio.

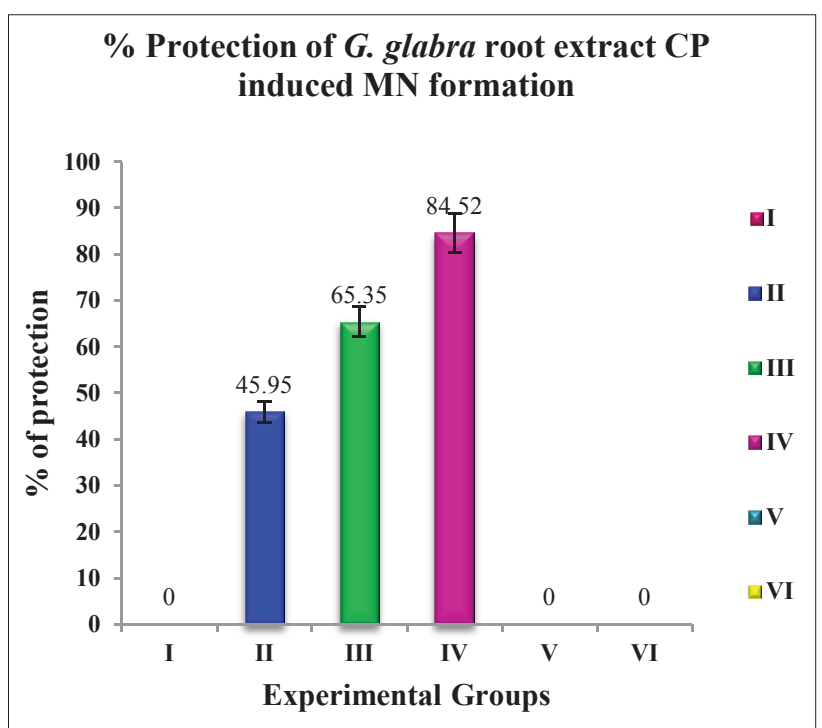

Figure 4: Effect of G. glabra root extract on \% of protection against $\mathrm{CP}$ induced $\mathrm{MN}$ formation.

effects on both resting and dividing lymphocytes. In that case, it is working as immunosuppressant. It is a potent anticancer drug, but it also affects normal cell division by decreasing the immune responses. The MN formation with $\mathrm{CP}$ administration showed that it has mutagenic behavior.

In present investigation, the root extract of Glycyrrhiza glabra exhibited anti-chemotherapeutic potential by decreasing the $\mathrm{MN}$ formation at the given doses. It may be due to the reducing immunosuppressant effects of $\mathrm{CP}$ and increasing the immune responses in the experimental animals. The presence of Glycyrrhizin, which is a triterpenoid saponin glycoside, stimulates medicinal properties of Glycyrhiza glabra Linn. From the above findings, it seems that, the hydromethanolic crude extract of Glycyrrhiza glabra possesses the anti-mutagenic 
potential. It may be because of the Glycyrrhizin and presence of many other phytoconstituents such as; tannins flavonoids, alkaloids, etc. The anti-mutagenic activity of the extract was found to be dose dependent. The significant anti-mutagenic activity in the above three different doses of Glycyrrhiza glabra extract against direct acting mutagens suggest that this extract may directly protect DNA damage from mutagens. The underlying mechanism behind the anti-mutagenic action of Glycyrrhiza glabra is still unknown.

Thus, there is an immense need to study the natural Glycyrrhiza constituents to reduce their toxic effects for generating the advanced versions of the bioactive compounds to be used as anti-mutagenic drugs from nature in future. Glycyrrhizin, glycyrrhetinic acid, glabridin and isoliquiritigenin hold a strong promise in designing future drugs.

\section{CONCLUSION}

It is concluded on the basis of results of present studies that acute administration of hydromethanolic root extract of Glycyrrhiza glabra may be safe as the $\mathrm{LD}_{50}$ determined. The present findings thus suggest that root extract of Glycyrrhiza glabra may be utilized to formulate anti-mutagenic drugs and in future it may be used as an alternative drug because most of the anticancer drugs used in present days showed mutagenic responses in animal models. Further studies are however needed to isolate and characterize the active principles responsible for anti-mutagenic activity. After that, this herbal formulation may include with the chemotherapy because it may be reduce the side-effects of chemotherapeutic agents and may increase the life span of patients who are suffering from cancer.

\section{ACKNOWLEDGMENTS}

The authors are thankful to Dr. S. K. Maheshwari, Medical Director of M. P. Birla Hospital, Satna, for providing lab facilities to carry out above work.

Funding: No funding sources

Conflict of interest: None declared

Ethical approval: The study was approved by the Institutional Animal Ethics Committee

\section{REFERENCES}

1. Yamamura Y, Kawakami J, Santa T, Kotaki H, Uchino K, Sawada Y, et al. Pharmacokinetic profile of glycerrhizin in healthy volunteers by a new high-performance liquid chromatographic method. J Pharm Sci. 1992;81:1042-6.
2. Zore GB, Winston UB, Surwase BS, Meshram NS, Sangle VD, Kulkarni SS, et al. Chemoprofile and bioactivities of Taverniera cuneifolia (Roth) Arn.: a wild relative and possible substitute of Glycyrrhiza glabra L. Phytomedicine. 2008;15:292-300.

3. Dong S, Inoue A, Zhu Y, Tanji M, Kiyama R. Activation of rapid signaling pathways and the subsequent transcriptional regulation for the proliferation of breast cancer MCF-7 cells by the treatment with an extract of Glycyrrhiza glabra root. Food Chem Toxicol. 2007;45:2470-8.

4. Asada Y, Li W, Yoshikawa T. Biosynthesis of the dimethylallyl moiety of glabrol in Glycyrrhiza glabra hairy root cultures via a non-mevalonate pathway. Phytochemistry. 2000;55:323-6.

5. Sharma V, Agrawal RC, Pandey S. Phytochemical screening and determination of anti-bacterial and anti-oxidant potential of Glycyrrhiza glabra root extracts. J Environ Res Dev. 2013;7(4A) :1552-8.

6. Hassan Mohd KA, Khalil S. A review: liquorice mouths wash as treatment for mouth ulcer. Int $\mathrm{J}$ Adv Pharm Sci. 2013;4(3) :335-40.

7. Lorke D. A new approach to practical acute toxicity testing. Arch Toxicol. 1983;54:275-87.

8. Turner R. Quantal responses and calculation of ED50. In: Screening Methods in Pharmacology. New York: Academic Press; 1965: 61-3.

9. Aliu YO, Nwude N. Veterinary Pharmacology and Toxicology Experiments. 1st Edition. Nigeria: Baraka Press and Publishers Ltd.; 1982: 104.

10. Schmid W. The micronucleus test. Mutat Res. 1975;31:9-15.

11. Aron CS, Sorg R, Zimmer D. The mouse bone marrow micronucleus test. Evaluation of 21 drug candidates. Mutat Res. 1989;223:129-40.

12. Agrawal RC, Kumar S. Prevention of cyclophosphomide induced micronucleus formation in mouse bone marrow by indole-3-carbinol. Food Chem Toxicol. 1998;3(6) :975-7.

13. Kumar R, Singh M. Tannins: their adverse role in ruminant nutrition. J Agric Food Chem. 1984;32:447-53.

14. Stormer FC, Reistad R, Alexander J. Glycyrrhizic acid in liquorice-evaluation of health hazard. Food Chem Toxicol. 1993;31:303-12.

15. Sofowora A. Medicinal Plants and Traditional Medicine in Africa. Ibadan, Nigeria: Spectrum Books Ltd.; 1993: 289.

16. Ammosov S, Litvinenko VI. Triterpenoids of plants of Glycyrrhiza L. and Meristotropis Fisch. Et Mey Genuses. Pharm Chem J. 2003;37:83-94.

17. Sheela ML, Ramakrishna MK, Salimath BP. Angiogenic and proliferative effects of the cytokine VEGF in Ehrlich ascites tumor cells is inhibited by Glycyrrhiza glabra. Int Immunopharmacol. 2006;6:494-8.

doi: 10.5455/2319-2003.ijbcp20140407

Cite this article as: Sharma V, Agrawal RC,

Shrivastava VK. Assessment of median lethal dose and antimutagenic effects of Glycyrrhiza glabra root extract against chemically induced micronucleus formation in Swiss albino mice. Int J Basic Clin Pharmacol 2014;3:292-7. 